\title{
Functional recombinant single-chain variable fragment antibody against Agkistrodon acutus venom
}

\author{
LEI ZHANG，YULIANG CAO，MINGHUA LIU，XIANGYU CHEN，QIANG XIANG and JUN TIAN
}

\author{
Department of Emergency, Southwest Hospital of the Third Military Medical University, Chongqing 400038, P.R. China
}

Received December 26, 2016; Accepted April 11, 2018

DOI: $10.3892 /$ etm.2019.7348

\begin{abstract}
Agkistrodon acutus bites are conventionally treated with animal-derived antivenom, the use of which is limited due to allergic reactions and serum sickness. Thus in the present study, the genes of humanized antibodies produced in response to A. acutus venom were extracted from lymphocytes from patients bitten by A. acutus. A single-chain variable fragment (scFv) library against venom was constructed using a T7 phage display system. ScFv genes that exhibited high affinity to venom were selected by library biopanning. An expression system was constructed for antivenom scFv fused with $6 x \mathrm{His}$ tag at its $\mathrm{N}$ - and C-terminus using pET-28a (+) vector. The ScFv proteins could achieve functional and soluble expression in Escherichia coli via the auto-induction method. The purity and activity of the $\mathrm{scFv}$ genes and proteins were confirmed by SDS-PAGE, western blotting and ELISA. The results indicated that three soluble $\mathrm{scFv}$ proteins exhibited specific affinity to A. acutus venom and were harvested via the auto-induction method.
\end{abstract}

\section{Introduction}

Agkistrodon acutus is one of the most common venomous snakes in China and Vietnam (1). A. acutus venom contains metalloproteinases, phospholipase C-type lectin-like proteins and serine proteases $(2,3)$. Snakebites of A. acutus can cause acute reactions, including tissue inflammation, edema, necrosis and hemorrhage, as well as clotting abnormalities, which can induce multiple organ failure $(4,5)$.

The treatment of A. acutus bites remains a controversial topic. Conventionally, animal-derived antivenom is administered to patients, but the clinical use of animal-derived antivenom has been limited due to frequent allergic reactions and serum sickness (6). In the last decade, antigen-specific

Correspondence to: Professor Minghua Liu, Department of Emergency, Southwest Hospital of the Third Military Medical University, 30 Gao Tan Yan Road, Chongqing 400038, P.R. China E-mail: mhliuswhcq@126.com

Key words: Agkistrodon acutus venom, single-chain variable fragment, phage display, auto-induction monoclonal antibodies have been applied therapeutically as antivenoms (7). However, the clinical application of monoclonal antibodies derived from animal sources is limited by immunogenicity and short half-life (8). Genetically engineered antibodies have been constructed to reduce immunogenicity and enhance performance (9). A basic functional unit of the antibody, the single-chain variable fragment ( $\mathrm{scFv}$ ) region, confers antigen specificity. Expressed $\mathrm{scFv}$ proteins possess advantages such as lower molecular weight, improved tissue penetration, and the potential to be prepared in vitro (10). Phage libraries of $\mathrm{scFv}$ gene repertoires are powerful tools for the isolation and identification of $\mathrm{scFv}$ molecules targeting specific antigens (11).

In the present study, to identify a potential treatment strategy for A. acutus bites, lymphocytes of two patients bitten by A.acutus were used to generate an scFv library, constructed in the $\mathrm{T} 7$ phage display system. The affinity of selected $\mathrm{scFv}$ proteins for A. acutus venom was probed by ELISA. The high-affinity $\mathrm{scFv}$ genes were introduced to a prokaryotic expression vector and functionally expressed in vitro.

\section{Materials and methods}

Ethics approval. The present study was approved by the Ethics Committee of Southwest Hospital of the Third Military Medical University (Chongqing, China). All patients provided written informed consent for their inclusion in the study.

RNA extraction and cDNA synthesis. Two female patients (Patient 1: Female, 21 years old, admitted to Southwest Hospital Emergency Department on August 4, 2011; Patient 2: Female, 33 years old, admitted to Southwest Hospital Emergency Department on August 14, 2011) who were hospitalized within $24 \mathrm{~h}$ of being bitten by $A$. acutus were recruited to the current study. The patients were then treated with 10 tablets $(0.4 \mathrm{~g} /$ tablet $)$ every $6 \mathrm{~h}$ of oral Jidesheng medicine (Jinghua Pharmaceutical Group Co., Ltd., Nantong city, China), a traditional Chinese snakebite medicine, together with rabies virus vaccine injection (Shanghai Serum Bio-technology Co., Ltd., Shanghai city, China). Blood samples $(5 \mathrm{ml})$ taken respectively at 48 and $96 \mathrm{~h}$ after treatments were pooled, and lymphocytes were isolated using Lymphocyte Cell Separation Medium (Sangon Biotech Co., Ltd., Shanghai, China), according to the manufacturer's protocol. Total RNA was extracted from isolated lymphocytes using TRNzol-A+ Reagent (Tiangen Biotech Co., Ltd., Beijing, 
China), according to the manufacturer's protocol, then mRNA was purified from extracted total RNA using Oligotex mRNA Mini kits (Qiagen GmbH, Hilden, Germany). Different purify cDNA was prepared respectively using reverse transcription using M-MLV Reverse Transcriptase (Invitrogen; Thermo Fisher Scientific, Inc., Waltham, MA, USA) with random hexamers starting with $1-5 \mu \mathrm{g}$ of total RNA or mRNA to a final volume of $20 \mu \mathrm{l}$.

Generation of human scFv gene repertoire. Primers for PCR amplification of human variable regions of light (VL) and heavy $(\mathrm{VH})$ chain genes were designed according to the degenerate primers described by Sblattero et al (12). The 5' ends of the human VL forward primers and $\mathrm{VH}$ reverse primers were modified include EcoRI and HindIII sites, respectively, for ligation into T7Select 10-3b DNA vector (EMD Millipore, Billerica, MA, USA). In order to splice the VL and VH amplicons, a complementary overlapping sequence (Linker-F and Linker-R) encoding a flexible linker of 12 amino acids was added to the $5^{\prime}$ ends of the human VL reverse primers and VH forward primers (13). Primers were designed to generate scFv genes using splicing by overlap extension-polymerase chain reaction (SOE-PCR) (Table I). PCR amplification of the human $\mathrm{VL}$ and $\mathrm{VH}$ genes was performed in a $50 \mu \mathrm{l}$ mixture containing $10 \mathrm{nM}$ of each forward and reverse primer, $4 \mu \mathrm{l}$ cDNA, $0.25 \mathrm{mM}$ each dNTP mixture, $10 \mu 1$ 5xPrimeSTAR ${ }^{\circledR}$ Buffer $\left(\mathrm{Mg}^{2+}\right.$ plus) and 0.5 units PrimeSTAR ${ }^{\circledR}$ polymerase (Takara Biotechnology Co., Ltd., Dalian, China). The amplification conditions comprised an initial denaturation at $95^{\circ} \mathrm{C}$ for $5 \mathrm{~min}$, followed by $35 \mathrm{PCR}$ cycles of $95^{\circ} \mathrm{C}$ for $20 \mathrm{sec}, 53^{\circ} \mathrm{C}$ for $20 \mathrm{sec}$ and $72^{\circ} \mathrm{C}$ for $30 \mathrm{sec}$, and a final extension step of $72^{\circ} \mathrm{C}$ for $5 \mathrm{~min}$. All amplified VL and VH genes were purified using the Qiaquick Gel Extraction kit (Qiagen $\mathrm{GmbH}$ ) in accordance with the manufacturer's protocol. The human $\mathrm{scFv}$ gene was generated by SOE-PCR. Briefly, the SOE-PCR reaction contained $100 \mathrm{ng}$ of purified VL products and $100 \mathrm{ng}$ of purified $\mathrm{VH}$ products, $10 \mathrm{nM}$ of $\mathrm{VH}-\mathrm{scFV}-\mathrm{F}$ and VL1/VL2-scFv-R primers, $0.25 \mathrm{mM}$ each dNTP mixture, $1 \times$ PrimeSTAR $^{\circledR}$ Buffer $\left(\mathrm{Mg}^{2+}\right.$ plus) and 0.5 units PrimeSTAR ${ }^{\circledR}$ polymerase. The cycling conditions for SOE-PCR were identical to those aforementioned. Total PCR products were subjected to $1.5 \%$ agarose gel electrophoresis and then visualized with ethidium bromide.

Cloning of human scFv gene repertoire into T7Select10-3b vector. The human $\mathrm{scFv}$ gene products were digested with restriction enzymes EcoRI and HindIII (New England BioLabs, Inc., Ipswich, MA, USA). After purification of the digested products, cohesive ligation of the $\mathrm{scFv}$ gene products $(0.12 \mathrm{pM})$ with T7Select $10-3 \mathrm{~b}$ EcoRI/HindIII Vector Arms (0.04 pM) (Merck, USA) was performed using T4 DNA Ligase (New England BioLabs, Inc.) at $16^{\circ} \mathrm{C}$ for $12 \mathrm{~h}$. The ligation products were added directly to $25 \mu \mathrm{l}$ T7 Packaging Extracts (EMD Millipore) and incubated for $2 \mathrm{~h}$ at $22^{\circ} \mathrm{C}$ for in vitro packaging. Sterile lysogeny broth $(270 \mu \mathrm{l})$ was added to stop the reaction. The primary scFv library was amplified by liquid lysate amplification according to the T7Select system manual. The titers of the primary and amplified library were determined by plaque assay, as described by the system manual.
$S c F v$ library screening. To screen for antigen-specific $\mathrm{scFv}$ that bound to $A$. acutus venom expressed in T7 phages, biopanning was performed to enrich venom-specific $\mathrm{scFv}$ phages according to the T7Select system manual. A. acutus venom protein was purchased from Guduo Biotechnology Inc. (Shanghai, China). Venom protein was dissolved in PBS to yield a stock solution of $10 \mathrm{mg} / \mathrm{ml}$, and diluted in PBS to $100 \mathrm{ng} / \mathrm{ml}$ for biopanning. A total of 12 phage clones were selected from output phages of the fourth round of biopanning, and their reactivity with venom protein was analyzed by phage ELISA (14).

Phage ELISA. Briefly, ELISA plates were coated with venom protein at a concentration of $10 \mu \mathrm{g} / \mathrm{ml}$ in $100 \mu \mathrm{l}$ Coating buffer (15 mM Na $\mathrm{CO}_{3}, 35 \mathrm{mM} \mathrm{NaHCO}$, $\mathrm{pH}$ 9.6) per well overnight at $4^{\circ} \mathrm{C}$. After soaking each well of the plate three times for 2 min with $200 \mu \mathrm{l}$ PBS containing $0.05 \%$ Tween-20 (PBST), the plate was blocked with PBST containing 5\% bovine serum albumin (Sigma-Aldrich; Merck KGaA, Darmstadt, Germany) at room temperature for $4 \mathrm{~h}$. Each well was then soaked with PBST three times in the conditions as aforementioned. Selected phages $\left(1 \times 10^{8} \mathrm{pfu}\right)$ were added to each well and incubated at $37^{\circ} \mathrm{C}$ for $1 \mathrm{~h}$. Bound phages were detected by horseradish peroxidase (HRP)-conjugated anti-T7 tag antibody (cat no. 69084; Merck KGaA), followed by a coloration reaction using the substrate 3,3'5,5'-tetramethylbenzidine (TMB; Tiangen Biotech Co., Ltd.). Absorbance at $450 \mathrm{~nm}$ was measured using a Synergy HT spectrometer (BioTek Instruments, Inc., Winooski, VT, USA). The phages generated by the T7Select control insert were used as negative controls. The sample OD450 value/negative control OD450 value was determined, and values $>2$ were considered positive.

Sequencing, expression and purification of $s c F v$. According to T7Select ${ }^{\circledR}$ System Manual, the phages with positive signal were amplified by PCR, which was performed in a $50 \mu \mathrm{l}$ mixture containing: $10 \mathrm{nM}$ sequencing primers T7selectUP and T7selectDOWN (Novagen, Merck, Germany) $2 \mu$ l phage $\left(>1 \times 10^{8} \mathrm{pfu}\right.$ ), $0.25 \mathrm{mM}$ of each dNTP mixture, $10 \mu 15$ xPrimeSTAR $^{\circledR}$ Buffer ( $\mathrm{Mg}^{2+}$ plus) and 0.5 units PrimeSTAR ${ }^{\circledR}$ polymerase (Takara Biotechnology Co., Ltd.). The amplification conditions comprised an initial denaturation at $95^{\circ} \mathrm{C}$ for $5 \mathrm{~min}$, followed by $35 \mathrm{PCR}$ cycles at $95^{\circ} \mathrm{C}$ for $15 \mathrm{sec}, 50^{\circ} \mathrm{C}$ for $15 \mathrm{sec}$ and $72^{\circ} \mathrm{C}$ for $30 \mathrm{sec}$, and a final extension step at $72^{\circ} \mathrm{C}$ for $5 \mathrm{~min}$. Products of PCR were sent to BGI Corporation (Shenzhen, China) for DNA sequencing. Positive PCR products and the pET28a (+) vector (Novagen) were digested with restriction enzymes EcoR I and Hind III. Then the digested vector and PCR products were ligated with T4 DNA ligase in a ratio of $1: 3$ overnight at $16^{\circ} \mathrm{C}$ The Escherichia coli BL21(DE3) competent cells were transformed with the ligation product and cultured on an LB medium plate (10 g/l Tryptone, $5 \mathrm{~g} / 1$ Yeast Extract, $10 \mathrm{~g} / 1 \mathrm{NaCl}, 1.5 \%$ Agar; Sangon Biotech Co., Ltd.) containing $50 \mu \mathrm{g} / \mathrm{ml}$ kanamycin for $12 \mathrm{~h}$ at $37^{\circ} \mathrm{C}$ to grow a positive colony that included the pET28a(+)-scFv recombinant plasmid. Positive colonies were selected and cultured on $200 \mathrm{ml}$ auto-induction medium (12 g/l tryptone, $24 \mathrm{~g} / 1$ yeast extract, $0.8 \%$ glycerol, $5 \mathrm{~g} / 1$ lactose, $0.15 \mathrm{~g} / 1$ glucose, $2 \mathrm{mM} \mathrm{MgSO}{ }_{4}, 0.38 \%$ aspartic acid, $17 \mathrm{mM} \mathrm{KH}_{2} \mathrm{PO}_{4}$, $72 \mathrm{mM} \mathrm{K}_{2} \mathrm{HPO}_{4}$ ) at $25^{\circ} \mathrm{C}$. At $24 \mathrm{~h}$ after auto-induction culture, the cells were harvested by centrifugation $\left(4,200 \times \mathrm{g}, 4^{\circ} \mathrm{C}\right.$, 
Table 1. Primer sequences for PCR and splicing by overlap extension-PCR.

\begin{tabular}{ll}
\hline Primer & \multicolumn{1}{c}{ Sequence (5'-3') } \\
\hline VH-01-F & TCGAGCGAATTCTCAGGTGCAGCTGCAGGAGTCSG \\
VH-02-F & TCGAGCGAATCTGAGGTGCAGCTGKTGGAGWCY \\
VH-03-F & TCGAGCGAATTCTCAGGTGCAGCTGGTGSARTCTGG \\
VH-01-R & GCCTCCACCTGATGAGGAGACRGTGACCAGGGT \\
VH-02-R & GCCTCCACCTGACGATGGGCCCTTGGTGGARGC \\
VH-03-R & GCCTCCACCTGAGGTTGGGGCGGATGCACTCC \\
VL1-01-F & GGTGGAGGCTCGGATATTGTGMTGACBCAGWCTCC \\
VL1-02-F & GGTGGAGGCTCGCAGTCTGTSBTGACGCAGCCGCC \\
VL1-01-R & ATGGTCAAGCTTTTGATYTCCASCTTGGTCC \\
VL1-02-R & ATGGTCAAGCTTTTAATCTCCAGTCGTGTCC \\
VL2-01-F & GGTGGAGGCTCGCAGCCTGTGCTGACTCARYC \\
VL2-02-F & GGTGGAGGCTCGCAGDCTGTGGTGACYCAGGAGCC \\
VL2-03-F & GGTGGAGGCTCGTCCTATGAGCTGAYRCAGCYACC \\
VL2-01-R & ATGGTCAAGCTTTAGGACGGTSASCTTGGTCC \\
VL2-02-R & ATGGTCAAGCTTGAGGACGGTCAGCTGGGTGC \\
VH-scFv-F & ACGTTATCCTCGAGCGAATTCTCAGGTG \\
V1-scFv-R & ACGGAAGTTATGGTCAAGCTTTTT \\
V2-scFv-R & ACGGAAGTTATGGTCAAGCTTTAGGAC \\
Linker-F & TCAGGTGGAGGCGGTTCTGGCGGAGGTGGCTCAGGCGGTGGAGGCTCG \\
Linker-R & CGAGCCTCCACCGCCTGAGCCACCTCCGCCAGAACCGCCTCCACCTGA
\end{tabular}

$\mathrm{S}=\mathrm{G} / \mathrm{C}, \mathrm{R}=\mathrm{G} / \mathrm{A}, \mathrm{K}=\mathrm{G} / \mathrm{T}, \mathrm{M}=\mathrm{A} / \mathrm{C}, \mathrm{Y}=\mathrm{C} / \mathrm{T}, \mathrm{W}=\mathrm{A} / \mathrm{T}, \mathrm{H}=\mathrm{A} / \mathrm{C} / \mathrm{T}, \mathrm{B}=\mathrm{C} / \mathrm{G} / \mathrm{T}, \mathrm{D}=\mathrm{A} / \mathrm{G} / \mathrm{T}$. PCR, polymerase chain reaction; VH, variable regions of heavy chain; VL, variable regions of light chain; $\mathrm{scFv}$, small-chain variable fragment; F, forward, R, reverse. The underlined section (GAA TTC or AAG CTT) refer to the restriction enzyme site of EcoR I or Hind III.

$10 \mathrm{~min}$ ), suspended in ice-cold lysis buffer (50 $\mathrm{mM} \mathrm{NaH}_{2} \mathrm{PO}_{4}$, $300 \mathrm{mM} \mathrm{NaCl}$ and $5 \mathrm{mM}$ imidazole, $1 \mathrm{mM}$ phenylmethylsulfonyl fluoride, $\mathrm{pH} 8.0$ ) and lysed by sonication (10 times, $4^{\circ} \mathrm{C}, 10 \mathrm{sec}$ interval). After centrifugation at $10,000 \times \mathrm{g}$ for $20 \mathrm{~min}$ at $4^{\circ} \mathrm{C}$, the $\mathrm{scFv}$ protein in soluble fraction was purified using Ni-nitrilotriacetic acid (NTA) agarose beads (Qiagen $\mathrm{GmbH}$ ) at $4^{\circ} \mathrm{C}$. Briefly, $1 \mathrm{ml}$ of Ni-NTA agarose was loaded into a QIAGEN-tip 500 column (Qiagen $\mathrm{GmbH}$ ) and equilibrated with $10 \mathrm{ml}$ of lysis buffer [50 mM NaH $\mathrm{PO}_{4}, 300 \mathrm{mM}$ $\mathrm{NaCl}$ and $5 \mathrm{mM}$ imidazole $(\mathrm{pH}$ 8.0)]. The soluble fraction was loaded onto the equilibrated columns. After loading, the column was washed with $50 \mathrm{ml}$ of washing buffer $(50 \mathrm{mM}$ $\mathrm{NaH}_{2} \mathrm{PO}_{4}, 300 \mathrm{mM} \mathrm{NaCl}$ and $20 \mathrm{mM}$ imidazole, $\mathrm{pH}$ 8.0). The bound $\mathrm{ScFv}$ protein was eluted with $5 \mathrm{ml}$ of elution buffer (50 $\mathrm{mM} \mathrm{NaH}_{2} \mathrm{PO}_{4}, 300 \mathrm{mM} \mathrm{NaCl}$ and $250 \mathrm{mM}$ imidazole, $\mathrm{pH}$ 8.0) and $1 \mathrm{ml}$ fractions were collected. The fractions were then dialyzed against PBS for $3 \mathrm{~h}$. The protein concentration was determined using a BCA protein assay kit (Beyotime Institute of Biotechnology, Haimen, China).

SDS-PAGE and western blot analysis. Purity of the Ni-NTA-purified ScFv was examined by SDS-PAGE and western blot analysis. $20 \mu \mathrm{g}$ purified proteins were separated on a $12 \%$ polyacrylamide gel at a constant electric current of $15 \mathrm{~mA}$ for $1.5 \mathrm{~h}$ and visualized by Coomassie blue staining. For western blot analysis, the proteins were transferred onto nitrocellulose membranes using the wet transfer method at a constant voltage of $80 \mathrm{~V}$ for $2 \mathrm{~h}$. The membrane was blocked with PBST containing 5\% non-fat milk at room temperature for $1 \mathrm{~h}$, then the blot was probed overnight at $4^{\circ} \mathrm{C}$ with a mouse anti-6xHis tag antibody (cat no. CW0082A; CWBio, Beijing, China) at 1:2,000 dilution. Following incubation with an HRP-conjugated goat anti-mouse IgG antibody (cat no. A0216; Beyotime Institute of Biotechnology) at 1:10,000 dilution for $2 \mathrm{~h}$ at room temperature, immune reactive bands were detected with an enhanced chemiluminescence kit (EMD Millipore).

ELISA analysis of the activity of anti-venom scFv. ELISA plates were coated with venom protein and utilized for the assay as described above. $\mathrm{ScFv}$ protein $(2 \mu \mathrm{g})$ was added to each well and incubated at $37^{\circ} \mathrm{C}$ for $2 \mathrm{~h}$. After washing with PBST three times in conditions as aforementioned, Horseradish peroxidase-labeled goat anti-human IgG (H+L; cat. no. A0201; Beyotime, China) was added to the plate and incubated at $37^{\circ} \mathrm{C}$ for $1 \mathrm{~h}$. After washing with PBST three times in conditions as aforementioned, bound $\mathrm{ScFV}$ protein was detected by a colorimetric assay with TMB as the substrate. Absorbance at $450 \mathrm{~nm}$ was measured. Horseradish peroxidase-labeled goat anti-human $\operatorname{IgG}(\mathrm{H}+\mathrm{L})$ was used as the negative control and PBS solution was used as the blank control. The sample OD450 value/negative control OD450 value was determined, and values $>2$ were considered positive.

Surface plasmon resonance analysis. The binding kinetics of soluble scFv and venom were analyzed using BiacoreX 
A

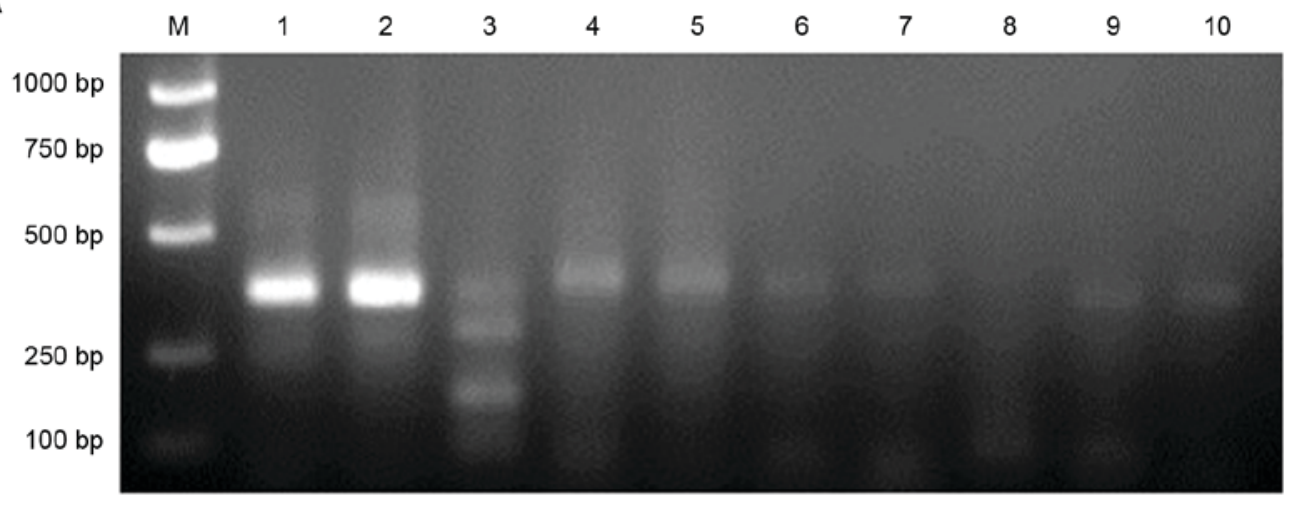

B

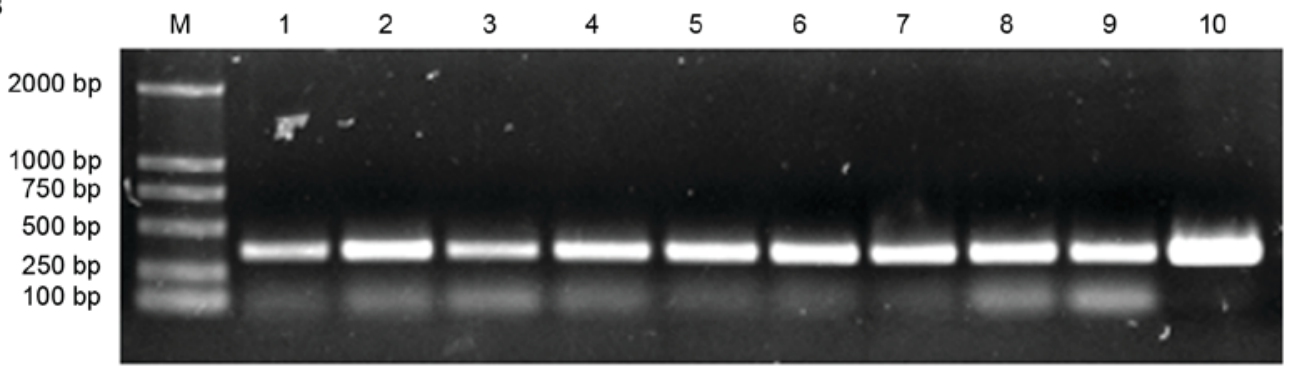

Figure 1. Amplification of human variable regions of light and heavy chain genes. Variable regions of light chains and heavy chains were amplified by reverse transcription polymerase chain reaction using (A) total RNA or (B) mRNA as the template. Lanes 1-5 present results from 5 reactions of light chains. Lanes 6-10 present results from 5 reactions of heavy chains. Lane M contains the DNA ladder. The products visible in the gels have apparent sizes of $\sim 360$ bp.

(GE healthcare Life Sciences, Little Chalfont, UK). The $K_{d}$ value of each purified scFv was calculated.

\section{Results}

Amplification of the VL and VH genes. Total mRNA, extracted and purified from the lymphocytes of patients, in addition to total RNA, was used as a template for reverse transcription of a cDNA substrate, then the VL and VH genes were amplified by PCR. As described previously, mRNA was a preferable substrate for specific and efficient amplification, in comparison with total RNA (14). Therefore the PCR products amplified from mRNA were used for library cloning. The major VL and VH PCR product sizes were approximately $360 \mathrm{bp}$ in length (Fig. 1). All VL and VH genes amplified by reverse transcription PCR were mixed and purified by gel filtration (Fig. 2A). Then, SOE-PCR was performed to generate full human $\mathrm{ScFV}$ genes. The resulting PCR products were approximately $750 \mathrm{bp}$ in length (Fig. 2B).

Generation and screening of the scFv library. The primary scFv library was generated through cloning the $\mathrm{scFv}$ gene repertoire into the T7Select10-3b vector and in vitro packaging. The primary library was amplified by liquid lysate method. The titer of the primary library was $4.6 \times 10^{9} \mathrm{pfu} / \mathrm{ml}$. The A. acutus venom-specific clones were enriched by a biopanning procedure, which was performed four times, and the resultant titer of enriched phages was $5.2 \times 10^{14} \mathrm{pfu} / \mathrm{ml}$.

Identification of positive scFv genes. A total of 12 clones were selected from the fourth generation phage library, and the affinity of these clones for venom was assessed by phage
ELISA. Of these phages, $50 \%$ exhibited affinity for venom (Fig. 3). PCR products of these phage clones were analyzed by agarose gel electrophoresis (Fig. 4) and positive products were sequenced. DNA sequence alignment demonstrated that positive $\mathrm{scFv}$ genes were heterozygote forms of the VL-Linker (12 animo acids)-VH (data not shown).

Soluble expression of $s c F v$ and evaluation of affinity to venom. Four scFv genes (B1-05, E1-03, E1-08 and G1-09) were cloned in multiple cloning sites of the pET-28a (+) vector and four scFv proteins were expressed in E. coli BL21 (DE3) by auto-induction (Fig. 5). Three of the four proteins exhibited solubility (Fig. 6) and could be purified and concentrated using a Ni-NTA agarose column (Fig. 7). ELISA results as shown in Fig. 8, PBS is blank control, anti-human $\operatorname{IgG}(\mathrm{H}+\mathrm{L})$ is negative control, three monomeric $\mathrm{scFv}$ showed positive reactions $(\mathrm{S} / \mathrm{N}$ value $>2$ ), demonstrated that $\mathrm{scFv}$ peptides possessed specific affinity for A. acutus venom.

Affinity analysis of anti-venom scFv by surface plasmon resonance. The affinity of the purified monomeric $\mathrm{scFv}$ and venom was analyzed using BiacoreX. As presented in Table II, the $K_{\text {on }}, K_{\text {off }}$, and $K_{\mathrm{d}}$ values of different scFvs were examined. The $K_{\mathrm{d}}$ value varied between 27.06 and $39.11 \mathrm{nmol} / 1$, indicating that the selected $\mathrm{scFv}$ exhibited a higher affinity activity.

\section{Discussion}

Natural A. acutus venom contains complex antigenic components (5), so therapeutic antibodies have thus far 
A

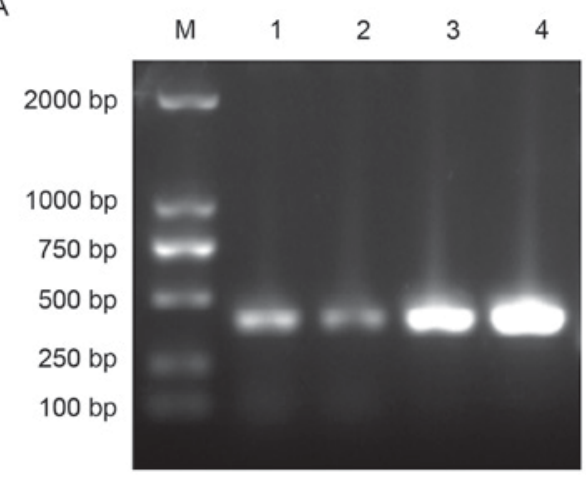

B 1

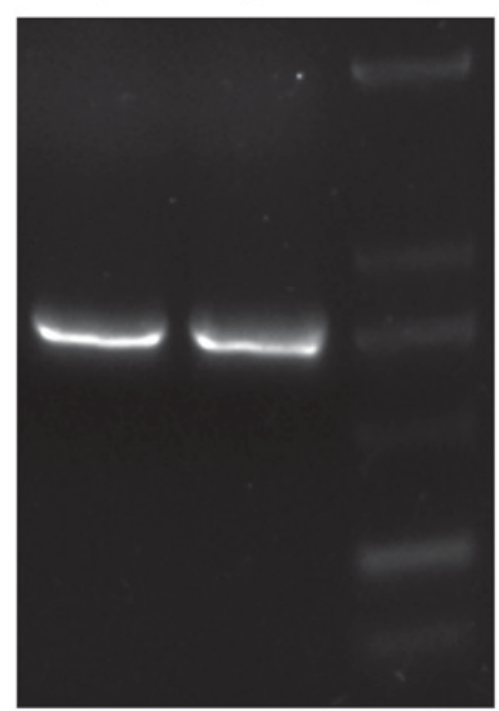

$2000 \mathrm{bp}$

$1000 \mathrm{bp}$

$750 \mathrm{bp}$

$500 \mathrm{bp}$

$200 \mathrm{bp}$

$100 \mathrm{bp}$

Figure 2. Generation of human scFv repertoires. (A) Total variable regions of light chain (lane 1 and 2) and variable regions of heavy chain (lanes 3 and 4) repertoires were purified by gel extraction. (B) Single-chain variable fragment regions (lanes 1 and 2) were amplified from the PCR products shown in (A) using splicing by overlap extension-PCR. Lane M contains the DNA ladder. PCR, polymerase chain reaction.

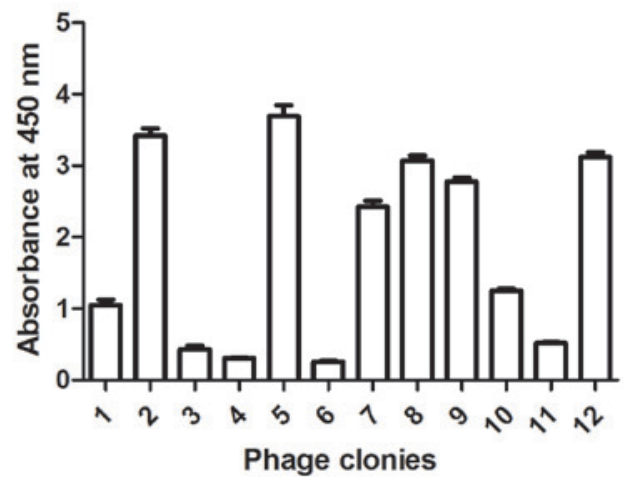

Figure 3. Identification of phage clone specificity. Affinity tests of cloned library. The binding of 12 phage clones to A. acutus venom was determined using ELISA assay. Data are presented as the mean \pm standard error from three independent experiments.

proven difficult to isolate using monoclonal antibody technology. $\mathrm{ScFv}$ cloning is an alternative method by which antigen-specific fusion immunoglobulin proteins can be

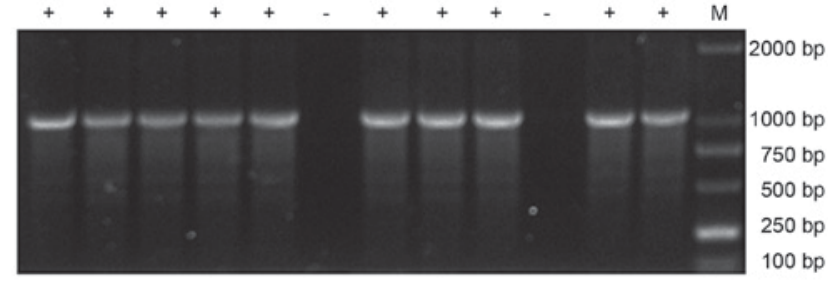

Figure 4. Identification of scFv gene sequence. Single-chain variable fragment regions of phage clones were amplified by polymerase chain reaction using sequencing primers. Lanes with + indicate clones that have been amplified, with positive bands $\sim 1,000 \mathrm{bp}$ ( $5^{\prime}$ and $3^{\prime}$ primer sequences + variable region of heavy chain + linker + variable region of light chain). Lane $\mathrm{M}$ contains the DNA ladder.

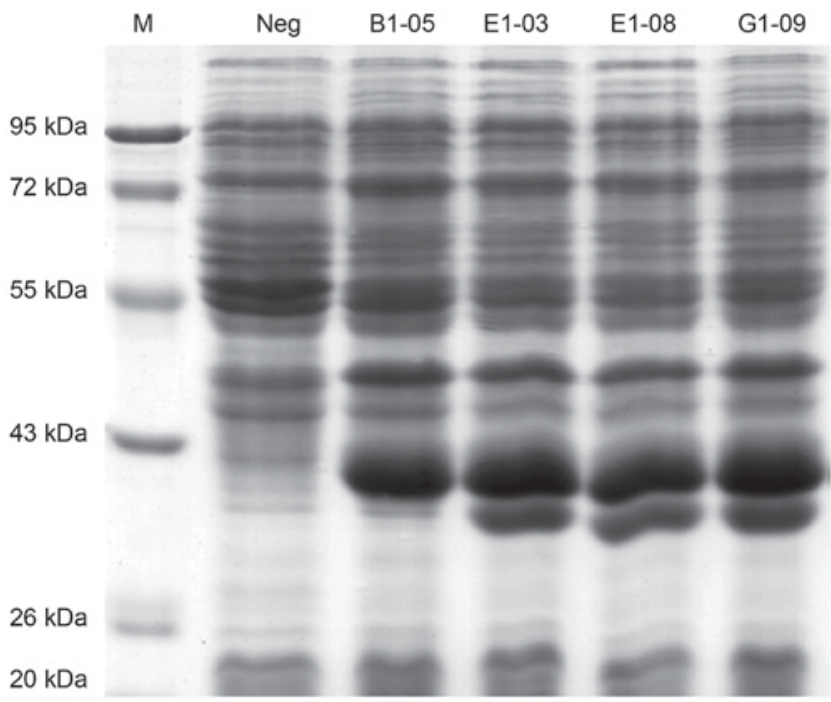

Figure 5. Expression of recombinant scFv protein. SDS-PAGE results indicated that four recombinant scFv proteins (B1-05, E1-03, E1-08 and G1-09) could be successfully expressed in E. coli . The protein bands were $\sim 35 \mathrm{kDa}$. Lane M contains the DNA ladder.
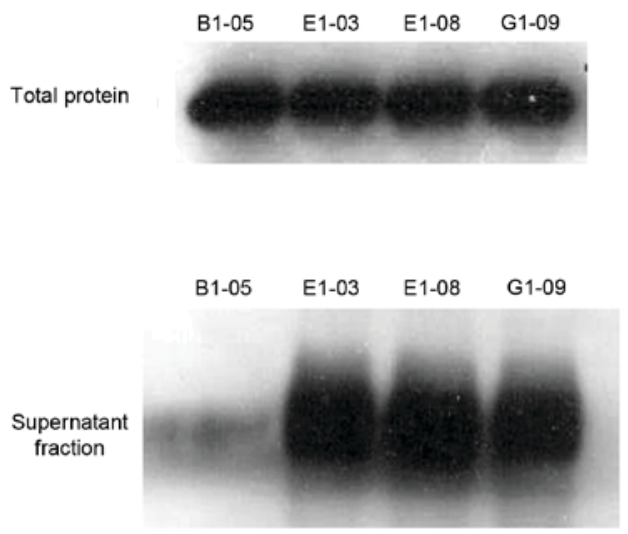

Figure 6. Determination recombinant scFv protein Solubility. Western blot analysis indicated that total bacterial protein of four scFvs could be detected by $6 \times$ His tag monoclonal antibody, with the exception of B105 in the supernatant fraction. The results revealed that B1-05 was insoluble body protein and E1-03, E-108 and G1-09 were soluble proteins.

generated. Cloning of $\mathrm{scFv}$ libraries has been widely used to generate specific $\mathrm{scFv}$, which exhibit improved pharmacokinetic properties compared with an intact antibody, including 

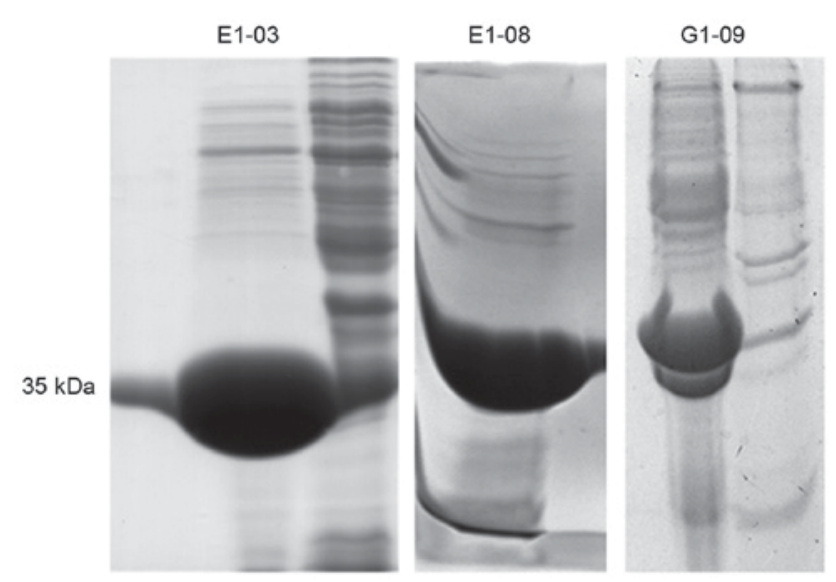

Figure 7. Purification of recombinant $\mathrm{scFv}$ proteins. SDS-PAGE results indicated that three soluble single-chain variable fragment proteins (E1-03, E1-08 and G1-09) were purified using Ni-nitrilotriacetic acid affinity chromatography.

better tissue penetration and rapid blood clearance (15-17). The present study aimed to identify A. acutus venom-specific antibodies. For this purpose, mRNAs were purified from the lymphocytes of patients who had been bitten by A.acutus. The immune response to the venom was likely to have amplified the repertoire of toxin-specific immunoglobulin genes. The amplicons of the VL and VH domains were connected by a flexible linker of 12 amino acids by SOE-PCR, generating an $\mathrm{scFv}$ gene library, which was then packaged in the T7Select Phage Display system. Unlike other phage display systems, the T7Select system is capable of displaying non-membrane proteins. In addition, due to the small size of scFv PCR products, non-membrane proteins can be well presented in the T7Select system (18-21). After four rounds of biopanning, specific anti-venom $\mathrm{scFv}$ presenting phages were enriched. Of the 12 randomly selected $\mathrm{scFv}$ clones, $50 \%$ exhibited affinity for venom in ELISA. DNA sequencing demonstrated that the sequences of these scFv clones varied (data not shown), further demonstrating the complexity of A. acutus venom.

To confirm that the encoded proteins of these $\mathrm{scFv}$ clones exhibited specificity to venom, four $\mathrm{scFv}$ sequences were selected from sequencing data to perform prokaryotic expression in E. coli BL21(DE3). In previous reports, recombinant $\mathrm{scFV}$ protein is often present in the form of an inclusion body protein during prokaryotic expression in E. coli; however, this original structure and its activity are lost following inclusion body renaturation (22-25). In the present study, due to high expression levels and a high probability of solubility for foreign proteins, the method of auto-induction was substituted for isopropyl $\beta$-D-1-thiogalactopyranoside (IPTG)-induction for protein expression (26). Indeed, the four $\mathrm{scFv}$ proteins selected exhibited insoluble expression or no expression in a preliminary experiment with IPTG-induction (data not shown). By contrast, three scFv proteins were purified using Ni-NTA chromatography for soluble expression by auto-induction culture. Each of these three scFv proteins exhibited a specific function to detect venom as antibodies in ELISA.

In the present study, an anti-A. acutus venom $\mathrm{scFv}$ phage library was constructed to select specific scFvs against venom.
Table II. Affinity analysis of anti-venom scFv by surface plasmon resonance.

\begin{tabular}{lllc}
\hline scFv & $\mathrm{K}_{\text {on }}(1 / \mathrm{ms})$ & $\mathrm{K}_{\text {off }}(1 / \mathrm{s})$ & $\mathrm{K}_{\mathrm{d}}(\mathrm{nmol} / \mathrm{l})$ \\
\hline E1-03 & $3.38 \times 10^{5}$ & $4.62 \times 10^{-3}$ & 30.58 \\
E1-08 & $3.22 \times 10^{5}$ & $1.84 \times 10^{-2}$ & 39.11 \\
G1-09 & $2.74 \times 10^{6}$ & $6.39 \times 10^{-2}$ & 27.06 \\
\hline
\end{tabular}

$\mathrm{scFv}$, single-chain variable fragment.

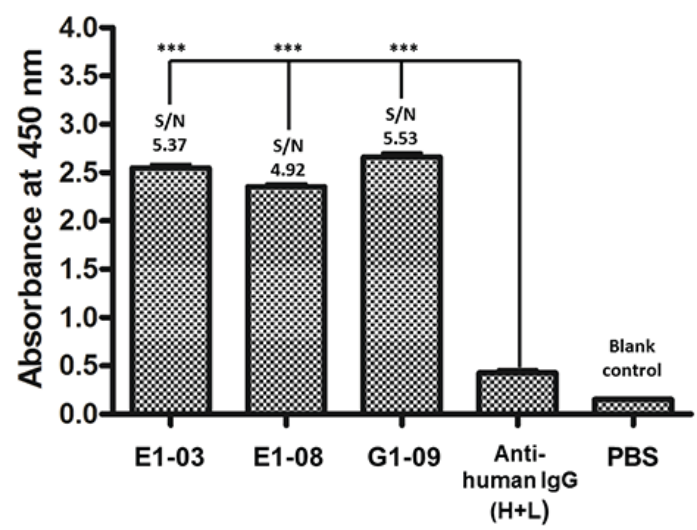

Figure 8. Specific binding of recombinant scFv proteins and venom. ELISA assay indicated that the three soluble scFv proteins (E1-03, E1-08 and G1-09) exhibit high binding specificity to Agkistrodon acutus venom. T7 Ab, horseradish peroxidase-conjugated anti-T7 tag antibody. ${ }^{* * *} \mathrm{P}<0.01$.

The recombinant proteins of these $\mathrm{scFv}$ genes were also screened and were determined to be soluble and expressed in E. coli. These results provide a foundation for the preparation of humanized therapeutic antibody in vitro to treat $A$. acutus bites.

\section{Acknowledgements}

Not applicable.

\section{Funding}

The present study was supported by the National Natural Science Foundation of China (grant no. 81071537), the Tackling Program of Science and Technology of Chongqing (grant no. CSTC $\backslash 2010 A C 5026$ ) and the Clinical Innovative Foundation of The Third Military Medical University (grant no. 2009XLC15).

\section{Availability of data and materials}

All data generated or analyzed during the present study are included in this published article.

\section{Authors' contributions}

LZ and YC performed the experiments and prepared the manuscript, under the supervision of ML. ML designed the current study and gave technical advice. JT, XC and QX acquired the data and provided critical advice during manuscript 
preparation. JT and ML revised the final text. All authors read and approved the final manuscript.

\section{Ethics approval and consent to participate}

Informed consent was obtained in all cases, and protocols were approved by the ethical committee of Third Military Medical University (Chongqing, China).

\section{Patient consent for publication}

The study was performed with the patients' informed consent.

\section{Competing interests}

The authors declare that they have no competing interests.

\section{References}

1. Kong Y, Huo JL, Xu W, Xiong J, Li YM and Wu WT: A nove anti-platelet aggregation tripeptide from Agkistrodon acutus venom: Isolation and characterization. Toxicon 54: 103-109, 2009.

2. Feng J, Chen T, Zhou M and Shaw C: Cloning of cDNAs and molecular characterisation of C-type lectin-like proteins from snake venoms. Toxicon 60: 1363-1369, 2012.

3. Jiang W, Ma T, Su X, Qiu P and Yan G: Enzymatic activities and functional characterization of a novel recombinant snake venom proteinase from Agkistrodon acutus. Biochimie 91: 277-287, 2009.

4. Luo S, Wang R, Jiang W, Lin X, Qiu P and Yan G: A novel recombinant snake venom metalloproteinase from Agkistrodon acutus protects against taurocholate induced severe acute pancreatitis in rats. Biochimie 92: 1354-1361, 2010.

5. Villalta M, Pla D, Yang SL, Sanz L, Segura A, Vargas M, Chen PY, Herrera M, Estrada R, Cheng YF, et al: Snake venomics and antivenomics of Protobothrops mucrosquamatus and Viridovipera stejnegeri from Taiwan: Keys to understand the variable immune response in horses. J Proteomics 75: 5628-5645, 2012.

6. Markland FS and Swenson S: Snake venom metalloproteinases. Toxicon 62: 3-18, 2013.

7. Azofeifa-Cordero G, Arce-Estrada V, Flores-Díaz M and Alape-Girón A: Immunization with cDNA of a novel P-III type metalloproteinase from the rattlesnake Crotalus durissus durissus elicits antibodies which neutralize $69 \%$ of the hemorrhage induced by the whole venom. Toxicon 52: 302-308, 2008.

8. Stas P and Lasters I: Immunogenicity of therapeutic antibodies. Med Sci (Paris) 25: 1070-1077, 2009 (In French).

9. Chames P and Baty D: The future of antibody fragments, made of a single immunoglobulin domain. Med Sci (Paris) 25: 1159-1162, 2009 (In French).

10. Cabezas S, Rojas G, Pavon A, Alvarez M, Pupo M, Guillen G and Guzman MG: Selection of phage-displayed human antibody fragments on Dengue virus particles captured by a monoclonal antibody: Application to the four serotypes. J Virol Methods 147: 235-243, 2008
11. Tang KH, Yusoff K and Tan WS: Display of hepatitis B virus PreS1 peptide on bacteriophage T7 and its potential in gene delivery into HepG2 cells. J Virol Methods 159: 194-199, 2009.

12. Sblattero D and Bradbury A: A definitive set of oligonucleotide primers for amplifying human $\mathrm{V}$ regions. Immunotechnology 3 : 271-278, 1998.

13. Haidaris CG, Malone J, Sherrill LA, Bliss JM, Gaspari AA, Insel RA and Sullivan MA: Recombinant human antibody single chain variable fragments reactive with Candida albicans surface antigens, J Immunol Methods 257: 185-202, 2001.

14. Wang S, Zheng C, Liu Y, Zheng $\mathrm{H}$ and Wang Z: Construction of multiform scFv antibodies using linker peptide. Genet J Genomics 35: 313-316, 2008.

15. Bhatia S, Gangil R, Gupta DS, Sood R, Pradhan HK and Dubey SC: Single-chain fragment variable antibody against the capsid protein of bovine immunodeficiency virus and its use in ELISA. J Virol Methods 167: 68-73, 2010.

16. Studier WF: Protein production by auto-induction in high-density shaking cultures. Protein Expr Purif 41: 207-234, 2005.

17. Monnier PP, Vigouroux RJ and Tassew NG: In vivo applications of single chain Fv (Variable Domain) $(\mathrm{scFv})$ fragments. Antibodies 2: 193-208, 2013.

18. Sun D, Shi H, Chen J, Shi D, Zhu Q, Zhang H, Liu S, Wang Y, Qiu $\mathrm{H}$ and Feng L: Generation of a mouse scFv library specific for porcine aminopeptidase $\mathrm{N}$ using the $\mathrm{T} 7$ phage display system. J Virol Methods 182: 99-103, 2012.

19. Sheets MD, Amersdorfer P, Finnern R, Sargent P, Lindqvist E, Schier R, Hemingsen G, Wong C, Gerhart JC and Marks JD: Efficient construction of a large nonimmune phage antibody library: The production of high-affinity human single-chain antibodies to protein antigens. Proc Natl Acad Sci USA 95: 6157-6162, 1998.

20. Lamberski JA, Thompson NE and Burgess RR: Expression and puriWcation of a single-chain variable fragment antibody derived from a polyol-responsive monoclonal antibody. Protein Expr Purif 47: 82-92, 2006.

21. Wan L, Zeng L, Chen L, Huang Q, Li S, Lu Y, Li Y, Cheng J and $\mathrm{Lu} \mathrm{X}$ : Expression, purification, and refolding of a novel immunotoxin containing humanized single-chain fragment variable antibody against CTLA4 and the N-terminal fragment of human perforin. Protein Expr Purif 48: 307-313, 2006.

22. Heo MA, Kim SH, Kim SY, Kim YJ, Chung J, Oh MK and Lee SG: Functional expression of single-chain variable fragment antibody against c-Met in the cytoplasm of Escherichia coli. Protein Expr Purif 47: 203-209, 2006.

23. Zhao Q, Chan YW, Lee SS and Cheung WT: One-step expression and purification of single-chain variable antibody fragment using an improved hexahistidine tag phagemid vector, Protein Expr Purif 68: 190-195, 2009.

24. Yang T, Yang L, Chai W, Li R, Xie J and Niu B: A strategy for high-level expression of a single-chain variable fragment against TNF $\alpha$ by subcloning antibody variable regions from the phage display vector pCANTAB 5E into pBV220. Protein Expr Purif 76: 109-114, 2011.

25. Bu D, Zhou Y, Tang J, Jing F and Zhang W: Expression and purification of a novel therapeutic single-chain variable fragment antibody against BNP from inclusion bodies of Escherichia coli, Protein Expr Purif 92: 203-207, 2013.

26. Deckert PM: Current constructs and targets in clinical development for antibody-based cancer therapy. Curr Drug Targets 10: 158-175, 2009. 